\title{
Analysis of muscle and bone weight variation in an Egyptian strain of Pekin ducklings
}

\author{
KA Shahin \\ Department of Animal Production, Faculty of Agriculture, Ain Shams University, PO Box 68 , \\ Hadayek Shoubra, 11241 Cairo, Egypt
}

(Received 26 May 1994 ; accepted 16 July 1995)

\begin{abstract}
Summary - A factor analysis with a varimax rotation was applied to ten muscle and bone traits on 144 Pekin ducklings to i) identify the main sources of shared variability, ii) deduce the factors controlling muscle and bone distribution, iii) predict the total amount of carcass muscle and bone from orthogonal muscle and bone traits. Muscle and bone weight distribution appeared to be controlled by both common and unique factors. The commonalities ranged from 0.76 (drumstick muscle) to 0.92 (neck bone) and the uniqueness (special size factors) made up the balance. The results indicated that most of the common variability $(84.3 \%)$ in muscle and bone weight distribution could be accounted for by factors representing muscle, bone, neck and drumstick bone factors. The correlation coefficient between the first factor score and carcass muscle was 0.90 and that between the second factor score and total carcass bone was 0.68 .
\end{abstract}

factor analysis / Pekin ducklings / multicollinearity / muscle weight variations/ bone weight variations

Résumé - Analyse de la répartition pondérale des muscles et des os chez une race égyptienne de canard Pekin. Une analyse de facteurs utilisant une rotation varimax a été appliqué à dix caractéristiques de muscle et d'os mesurées sur 144 canards Pekin afin de : i) identifier les principales sources de variabilité commune, ii) déterminer les facteurs contrólant la répartition des muscles et des os, iii) prédire la quantité totale de muscles et d'os dans la carcasse à partir du muscle orthogonal et des caractéristiques des os. La répartition pondérale des muscles et des os semble contrôlée à la fois par des facteurs communs et des facteurs spécifiques. Les facteurs communs ont un effet compris entre 0,76 (pour le muscle du pilon) et 0,92 (pour les os du cou). Les facteurs spécifiques (ex : facteurs de la taille) influencent l'équilibre muscle/os. Les résultats obtenus montrent que l'essentiel de la variabilité $(84,3 \%)$ de la répartition pondérale des muscles et des os peut être attribuée à quatre facteurs communs : les facteurs des muscles, des os, du cou et du pilon. Le coefficient de corrélation entre le facteur numéro 1 et les muscles de la carcasse était de 0,90 et celui entre le facteur numéro 2 et les os de la carcasse de 0,68.

analyse de facteurs / canard Pekin / répartition pondérale / muscle / os 


\section{IINTRODUCTION}

Correlations between muscle and bone traits characterizing size and shape may be different if these traits are treated as bivariates rather than as multivariates. Multicollinear data analysis with multiple regression and allied techniques (on chickens, eg, Herstad and Frisch, 1972; Ricard, 1972; on cattle, eg, Williams et al, 1974; on ducks, eg, Stasko, 1965; Clayton and Draper, 1971; Clayton et al, 1974; Janiszewska et al, 1983; Ricard, 1987; on geese, eg, Wawro et al, 1985) may limit the use of such analysis for inference and forescasting (Mather, 1976; Chatterjee and Price, 1977; Stopher and Meyburg, 1979; Shahin et al, 1993).

Independent factor scores derived from a factor analysis technique (Morrison, 1967; Blackith and Reyment, 1971; Pimentel, 1979), allowing the orthogonalization of sets of traits, can be used as predictors of total carcass muscie and bone and other performance traits. Thorough factor analysis partitioning of the entire variance of each variable into common (shared with some or all variable) and unique variance (specific to a particular variable) is required for effective selection programs. Klijn (1976) used factor analysis to identify which part of the variance in a muscle's weight can be accounted for by common factors and which part by unique factors.

One objective of this study was to investigate the hypothesis of different models for the relationships between the weight of muscle and bone in various carcass parts with the corresponding weight of that tissue in a carcass by applying factor analysis to the interrelation traits rather than by simple and multiple regressions. A second objective was to identify the main sources of shared variability and deduce the factors that control muscle and bone distribution in Pekin ducklings.

\section{MATERIALS AND METHODS}

One hundred and forty-four (equal number of males and females) Pekin ducklings, of approximately $1683 \mathrm{~g}$ in live weight and 10 weeks of age, were studied. The birds were sacrificed by severing the carotid artery and jugular veins. The head was removed at the atlantooccipital articulation. Carcasses were stored at $-20^{\circ} \mathrm{C}$. Prior to cutting and dissection, carcasses were thawed for approximately $8 \mathrm{~h}$ at $5^{\circ} \mathrm{C}$, in their bags. The right side of each carcass was then jointed into the following commercial cuts: thigh, drumstick, wing, breast, neck and tail as described by Shahin (1990). In each, cut skin, subcutaneous fat, intermuscular fat, muscle and bone were dissected and weighed. The sum of muscle and intermuscular fat formed the lean. The sum of these parts over all cuts gave total side lean, total side bone and total side skin plus subcutaneous fat. The data from males and females were combined since the two data dispersion matrices did not differ significantly (untabulated).

\section{STATISTICAL ANALYSIS}

The data were subjected to a factor analysis procedure (SAS, 1988). The main source of shared variation among highly correlated meatiness and bone variables $(n)$ was expressed in terms of a few mutually uncorrelated common factors (unknown variables or latent variables), $F_{1}, \ldots, F_{m}$ (where $m<n)$, then the original number of variables (Morrison, 1967; Blackith and Reyment, 1971). The first factor contained the greatest portion of original variation. Subsequent factors were mutually orthogonal to those preceding and to one another and contained less variation. To give the initial factor solution, a 'simple structure' varimax rotation (Kaiser, 1958) was performed. Varimax rotations (Pimentel, 1979) seek to maximize the variance of the loadings on each factor such that the variables having the highest loadings on a factor tend to have near-zero loadings on all others. The sum of variances of all retained factors is the total common variance. 
The general model for factor analysis was:

$$
X_{j}=\left(a_{j 1} F_{1}+a_{j 2} F_{2}+\ldots+a_{j m} F_{m}\right)+d_{j} U_{\mathrm{j}}
$$

where $X_{j}=$ variable $j(j=1,2, \ldots, n) ; F_{1}=$ common factors affecting all variables $(i=1$, $2, \ldots, m) ; a_{j i}=$ factor loading representing the correlation of the variable with the factor; $d_{j}=$ factor loading of variable $j$ on unique factor $j ; U_{j}=$ factor related to each particular variable affecting a single variable.

The total variance of $X$ is equal to unity and can be written as the sum of common variance 'commonalities, $h^{2}$ ', and unique variance 'uniqueness, $u^{2}$ ' as follows:

$$
\operatorname{Var}\left(X_{\mathrm{j}}\right)=1=h_{j}^{2}+u_{j}^{2}
$$

where $h_{j}^{2}=\sum_{i=1}^{m} a_{j i}^{2}$,

representing the portion of the variable variance accounted for by all common factors; $u_{j}^{2}=1-h_{j}^{2}$ 'latent variance', representing the portion of the variable variance accounted for by a unique factor (that is not shared with other variables).

A built-up stepwise multiple regression (Drapper and Smith, 1981) was used to predict total side muscle weight and total side bone weight from the orthogonal factor scores derived from the factor analysis.

\section{RESULTS AND DISCUSSION}

Table I presents the means, standard deviations, the coefficient of variability and ranges for live weight and muscle and bone traits. Body weight averaged $1683 \mathrm{~g}$ and ranged from 1000 to $2100 \mathrm{~g}$. Total side muscle weight ranged from 100 to $325 \mathrm{~g}$ with a mean of $236 \mathrm{~g}$ and total side bone weight ranged from 61 to $126 \mathrm{~g}$ with a mean of $99 \mathrm{~g}$. The carcass muscle:bone ratio ranged from 1.63 to 3.25 with a mean of 2.39.

The breast muscle accounted for $27.8 \%$ of the total carcass muscle weight and the thigh muscle accounted for $20.1 \%$ of the total carcass muscle weight. The wing bone (scapula, humerus, radius and ulna) accounted for $21.5 \%$ of the total carcass bone weight and the thigh bone accounted for $20.6 \%$ of the total carcass bone weight. The muscle: bone ratio, 'fleshiness', for various parts of the carcass are also shown in table I.

\section{NONINDEPENDENT MUSCLE AND BONE TRAITS, THEIR INTERRE- LATIONS AND RELATIONSHIPS WITH INDEPENDENT FACTOR SCORES}

The coefficients of correlation among all carcass traits are presented in table II. The weight of muscle or bone in all carcass parts was highly correlated with the corresponding weight of that tissue in the carcass. Total carcass muscle had the highest correlation with breast muscle weight and total carcass bone had the highest correlation with wing bone. Muscle and bone traits were highly intercorrelated. Similar findings have been reported by Klijn (1976), Wawro et al (1984) and Shahin (1990).

In the present study, the separable muscle in the thigh was associated with $72 \%$ of the variation in total separable carcass muscle, while in beef cattle, Cole et al (1960) reported the separable muscle in the round 'thigh' was associated with $90 \%$ of the variation in separable carcass muscle.

Correlations among the interdependent carcass traits with nonrotated orthogonal factor scores showed that the first factor score, representing general size 'muscling', was highly correlated $(P<0.01)$ with each trait (table III). The highest correlation (0.84) was with the thigh muscle, indicating that 
Table I. Means, standard deviations (SD), coefficient of variability (CV\%) and minimum and maximum values for live and carcass traits.

\begin{tabular}{|c|c|c|c|c|}
\hline & Mean & $S D$ & $C V \%$ & Range \\
\hline Live weight $(\mathrm{g})$ & 1682.6 & 209.6 & 12.5 & $1000-2100$ \\
\hline Dissected side weight (g) & 469.3 & 76.1 & 16.2 & $257.4-618.2$ \\
\hline Total side muscle $(\mathrm{g})$ & 235.5 & 40.1 & 17.0 & $100.3-324.5$ \\
\hline Total side bone $(\mathrm{g})$ & 98.6 & 10.2 & 10.3 & $60.9-125.9$ \\
\hline Total side fat $(\mathrm{g})$ & 135.3 & 43.7 & 32.3 & $47.3-258.2$ \\
\hline Total side subcutaneous fat $(\mathrm{g})$ & 121.7 & 40.0 & 32.9 & $44.3-235.4$ \\
\hline Total side intermuscular fat $(\mathrm{g})$ & 13.6 & 5.4 & 39.7 & $3.0-28.7$ \\
\hline \multicolumn{5}{|l|}{$\%$ of Live weight } \\
\hline Total muscle & 27.9 & 2.8 & 9.9 & $19.9-34.2$ \\
\hline Total bone & 11.8 & 1.0 & 8.7 & $9.0-14.9$ \\
\hline Total fat & 15.9 & 4.2 & 26.6 & $6.7-25.2$ \\
\hline Total subcutaneous fat & 14.3 & 3.9 & 27.4 & $6.2-23.5$ \\
\hline Total intermuscular fat & 1.6 & 0.5 & 33.5 & $0.5-2.8$ \\
\hline \multicolumn{5}{|l|}{$\%$ of Total muscle } \\
\hline Drumstick muscle & 13.9 & 1.5 & 11.1 & $10.5-18.5$ \\
\hline Thigh muscle & 20.1 & 2.1 & 10.4 & $15.9-30.1$ \\
\hline Breast muscle & 27.8 & 5.5 & 19.9 & $11.9-40.5$ \\
\hline Wing muscle & 14.1 & 1.4 & 10.0 & $9.0-17.8$ \\
\hline Neck muscle & 10.2 & 1.6 & 15.4 & $7.3-14.6$ \\
\hline \multicolumn{5}{|l|}{$\%$ of Total bone } \\
\hline Drumstick bone & 11.8 & 1.2 & 10.0 & $8.5-17.4$ \\
\hline Thigh bone & 20.6 & 1.6 & 7.8 & $16.3-28.0$ \\
\hline Breast bone & 15.7 & 1.6 & 10.1 & $9.7-19.4$ \\
\hline Wing bone & 21.5 & 2.1 & 9.6 & $12.8-27.9$ \\
\hline Neck bone & 15.7 & 2.3 & 14.3 & $12.2-25.5$ \\
\hline \multicolumn{5}{|l|}{ Muscle:bone ratio in: } \\
\hline Drumstick & 2.8 & 0.4 & 14.6 & $1.7-5.2$ \\
\hline Thigh & 2.3 & 0.2 & 10.4 & $1.7-3.0$ \\
\hline Breast & 4.3 & 1.2 & 28.0 & $1.8-7.7$ \\
\hline Wing & 1.6 & 0.3 & 17.2 & $0.9-2.4$ \\
\hline Neck & 1.6 & 0.2 & 13.6 & $1.1-2.1$ \\
\hline Whole carcass & 2.4 & 0.3 & 13.8 & $1.6-3.3$ \\
\hline
\end{tabular}

$70.7 \%$ of the total phenotypic variance in the thigh muscle was explained by a general size factor (factor 1). The initial solution (table III) identified the principal patterns of variation in the original variables. As it was difficult to interpret them meaningfully (distinctive clusters of variables were not obvious), a further step (varimax rotation) was required.
Breast muscle weight alone accounted for $89 \%$ of the variability in the total side muscle weight. Multiple correlations (table IV) showed that $R^{2}$ increased from 0.96 , $0.98,0.99$ and residual standard deviation of the estimate decreased from 8.4 to 6.4 to 4.7 to $3.8 \mathrm{~g}$ with the stepwise addition of the thigh muscle, neck muscle, wing muscle and drumstick muscle, respectively. These 
Table II. Coefficient of correlation between variables.

$\begin{array}{lllllllllllll}W & T S M & T S B & D M & T M & B M & W M & N M & D B & T B & B B & W B & N B\end{array}$

Live weight $(L W)$

Total side muscle (TSM) 0.840

Total side bone (TSB) $\quad 0.736 \quad 0.624$

$\begin{array}{llll}\text { Drumstick muscle (DM) } & 0.787 & 0.800 & 0.619\end{array}$

$\begin{array}{llllll}\text { Thigh muscle (TM) } & 0.717 & 0.846 & 0.573 & 0.707\end{array}$

$\begin{array}{llllll}\text { Breast muscle (BM) } & 0.720 & 0.944 & 0.495 & 0.668 & 0.704\end{array}$

$\begin{array}{llllllll}\text { Wing muscle (WM) } & 0.740 & 0.893 & 0.519 & 0.710 & 0.751 & 0.802\end{array}$

$\begin{array}{lllllllll}\text { Neck muscle (NM) } & 0.680 & 0.583 & 0.605 & 0.575 & 0.566 & 0.385 & 0.493\end{array}$

$\begin{array}{lllllllll}\text { Drumstick bone (DB) } & 0.351 & 0.292 & 0.589 & 0.326 & 0.367 & 0.175 & 0.248 & 0.338\end{array}$

$\begin{array}{lllllllllll}\text { Thigh bone (TB) } & 0.609 & 0.569 & 0.763 & 0.562 & 0.600 & 0.466 & 0.500 & 0.452 & 0.520\end{array}$

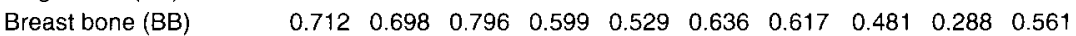

$\begin{array}{lllllllllllll}\text { Wing bone (WB) } & & 0.618 & 0.617 & 0.808 & 0.547 & 0.557 & 0.530 & 0.552 & 0.498 & 0.356 & 0.650 & 0.702\end{array}$

$\begin{array}{lllllllllllll}\text { Neck bone (NB) } & 0.389 & 0.070 & 0.532 & 0.231 & 0.112-0.107 & 0.001 & 0.579 & 0.240 & 0.268 & 0.331 & 0.264\end{array}$

Table III. Explained variation associated with unrotated factor analysis. Correlations between factor score coefficients and original variables.

\begin{tabular}{lccrr} 
& \multicolumn{3}{c}{ Common factors } & - \\
& 1 & 2 & 3 & - \\
& & & - & - \\
& & & - & - \\
Drumstick muscle & 0.838 & -0.094 & -0.114 & 0.199 \\
Thigh muscle & 0.841 & -0.193 & 0.036 & 0.278 \\
Breast muscle & 0.778 & -0.501 & -0.091 & -0.005 \\
Wing muscle & 0.826 & -0.400 & -0.097 & 0.126 \\
Neck muscle & 0.713 & 0.403 & -0.306 & 0.308 \\
Drumstick bone & 0.489 & 0.364 & 0.703 & 0.195 \\
Thigh bone & 0.767 & 0.157 & 0.357 & -0.168 \\
Breast bone & 0.801 & 0.027 & -0.151 & -0.424 \\
Wing bone & 0.789 & 0.083 & 0.054 & -0.440 \\
Neck bone & 0.321 & 0.843 & -0.327 & -0.004 \\
& & & & 6.7
\end{tabular}

results indicated that total muscle weight can be predicted with a high degree of accuracy from breast and thigh muscles: as much as $96 \%$ of the variation in total muscle weight was accounted for by these two traits.

The wing bone (ossa alae) alone accounted for $65 \%$ of the variability in the total side bone weight. Multiple correlations (table V) showed that $R^{2}$ increased to 0.76 , $0.84,0.88$ and 0.92 and residual standard deviation of the estimate decreased to 4.99 , $4.2,3.5$ and $3.0 \mathrm{~g}$ with stepwise addition of the neck bone, thigh bone, breast bone and drumstick bone, respectively.

In chickens, the tibia, femur, coracoid, humerus and sternum (breast bone) were 
Table IV. Stepwise multiple regression of total side muscle weight $(g)$ on original muscle traits.

\begin{tabular}{|c|c|c|c|c|c|c|}
\hline Step & $\begin{array}{l}\text { Independent variables } \\
\text { (predictors) }\end{array}$ & Intercept & $\begin{array}{l}\text { Regression } \\
\text { coefficient } b\end{array}$ & $S E$ & $\mathrm{R}^{2}$ & $\begin{array}{c}\text { Residual } \\
\text { standard deviation }\end{array}$ \\
\hline- & $\begin{array}{lll}- & - & -\end{array}$ & & & & & $-\quad-\quad-$ \\
\hline 1 & Breast muscle & 120.64 & 1.71 & 0.05 & 0.891 & 13.28 \\
\hline \multirow[t]{2}{*}{2} & Breast muscle & 35.19 & 1.25 & 0.04 & 0.957 & 8.40 \\
\hline & Thigh muscle & & 2.50 & 0.17 & & \\
\hline \multirow[t]{3}{*}{3} & Breast muscle & 19.56 & 1.25 & 0.03 & 0.975 & 6.36 \\
\hline & Thigh muscle & & 1.83 & 0.14 & & \\
\hline & Neck muscle & & 1.96 & 0.19 & & \\
\hline \multirow[t]{4}{*}{4} & Breast muscle & 18.77 & 1.06 & 0.03 & 0.987 & 4.67 \\
\hline & Thigh muscle & & 1.40 & 0.11 & & \\
\hline & Neck muscle & & 1.70 & 0.14 & & \\
\hline & Wing muscle & & 1.21 & 0.11 & & \\
\hline \multirow[t]{5}{*}{5} & Breast muscle & 7.82 & 1.02 & 0.02 & 0.991 & 3.84 \\
\hline & Thigh muscle & & 1.22 & 0.10 & & \\
\hline & Neck muscle & & 1.40 & 0.12 & & \\
\hline & Wing muscle & & 1.06 & 0.09 & & \\
\hline & Drumstick muscle & & 1.06 & 0.12 & & \\
\hline
\end{tabular}

Table V. Stepwise multiple regression of total side bone weight $(\mathrm{g})$ on original bone traits.

\begin{tabular}{|c|c|c|c|c|c|c|}
\hline Step & $\begin{array}{l}\text { Independent variables } \\
\text { (predictors) }\end{array}$ & Intercept & $\begin{array}{l}\text { Regression } \\
\text { coefficient } b\end{array}$ & $S E$ & $\mathrm{R}^{2}$ & $\begin{array}{c}\text { Residual } \\
\text { standard deviation }\end{array}$ \\
\hline 1 & Wing bone & 42.59 & 2.63 & 0.16 & 0.653 & 6.00 \\
\hline 2 & $\begin{array}{l}\text { Wing bone } \\
\text { Neck bone }\end{array}$ & 27.12 & $\begin{array}{l}2.34 \\
1.40\end{array}$ & $\begin{array}{l}0.14 \\
0.17\end{array}$ & 0.762 & 4.99 \\
\hline 3 & $\begin{array}{l}\text { Wing bone } \\
\text { Neck bone } \\
\text { Thigh bone }\end{array}$ & 12.78 & $\begin{array}{l}1.60 \\
1.25 \\
1.59\end{array}$ & $\begin{array}{l}0.15 \\
0.15 \\
0.20\end{array}$ & 0.836 & 4.16 \\
\hline 4 & $\begin{array}{l}\text { Wing bone } \\
\text { Neck bone } \\
\text { Thigh bone } \\
\text { Breast bone }\end{array}$ & 11.89 & $\begin{array}{l}1.03 \\
1.07 \\
1.38 \\
1.30\end{array}$ & $\begin{array}{l}0.15 \\
0.13 \\
0.17 \\
0.18\end{array}$ & 0.881 & 3.54 \\
\hline 5 & $\begin{array}{l}\text { Wing bone } \\
\text { Neck bone } \\
\text { Thigh bone } \\
\text { Breast bone } \\
\text { Drumstick bone }\end{array}$ & 0.77 & $\begin{array}{l}1.00 \\
0.97 \\
0.89 \\
1.36 \\
1.94\end{array}$ & $\begin{array}{l}0.12 \\
0.11 \\
0.16 \\
0.15 \\
0.25\end{array}$ & 0.918 & 2.97 \\
\hline
\end{tabular}


the most common predictors of total carcass bone used by many investigators (Martin and Patrick, 1962; Morris et al, 1966; Cox and Ballonn, 1971). It is worth mentioning that, the humerus bone in ducks is the longest bone in the skeleton, while in chickens and turkeys, the tibia is the longest and largest bone in the skeleton.

\section{INDEPENDENT FACTORS AND THEIR INTERPRETATION}

In order to improve the factor interpretability and to simplify the structure of the factors, the varimax final solutions were applied and are presented in table $\mathrm{VI}$ and figure 1 . This involved rotating the factor axes until distinct clusters of variables were more readily identifiable (ie, each factor is defined by a few high loadings). The factor analysis technique reduced (condensed or amalgamated) the entire set of correlations of the ten meatiness and bone traits into four linearly independent functions of the original variables.
Four common factors were identified, contributing to $84 \%$ of the variability of the original ten variables, leaving $16 \%$ to ten 'special' factors.

The first factor was characterized by high positive loadings (factor-variate correlations) on all meatiness traits; the variables associated with the wing muscle and breast muscle had the highest loadings, followed by the thigh muscle and drumstick muscle. This factor, accounting for $54 \%$ of the variation in the original variables, can be interpreted as a general size factor or an index of general 'meatiness' (bone independent), analogous to comparable interpretations by Ricard and Rouvier (1966) and Rouvier and Ricard (1967). Klijn (1976) found that muscle weight variability depends on body size (factor 1) for $66 \%$ of the total variance in the wing and $57 \%$ in the leg.

The subsequent factors were mutually orthogonal (essentially uncorrelated) to the first, present patterns of variation and were independent of general size (multicollinearity was no longer present). The intercorre-

Table VI. Explained variation associated with rotated factor analysis. Correlations between factor score coefficients and original variables.

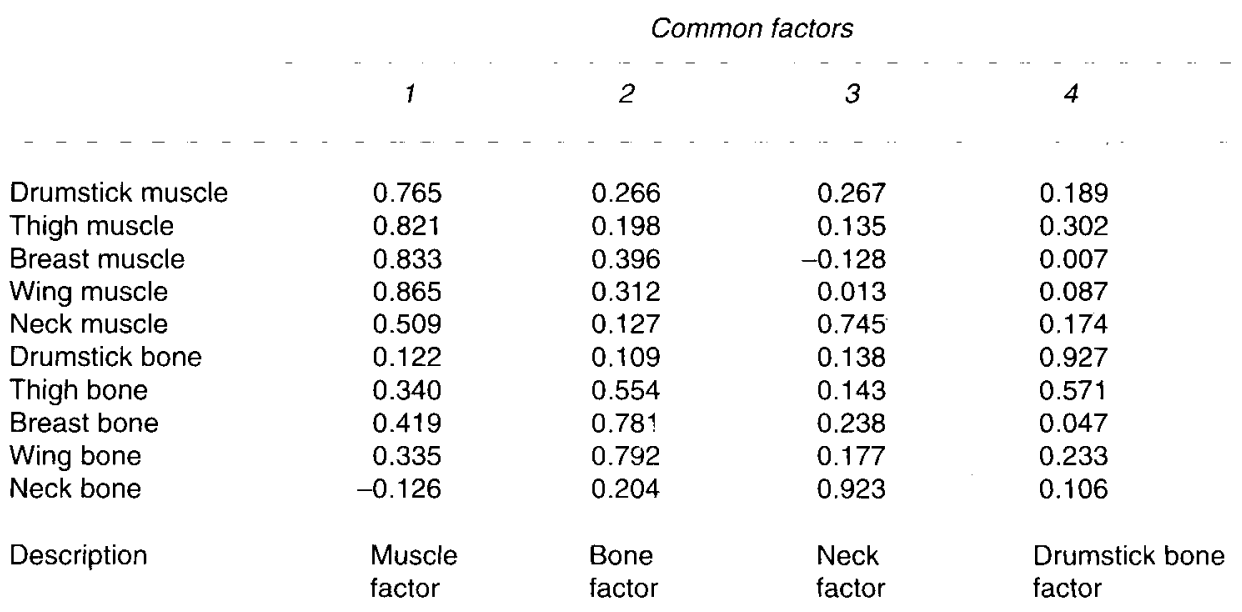




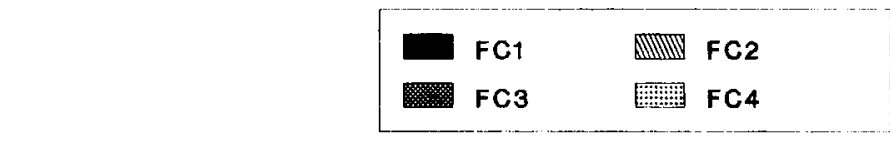

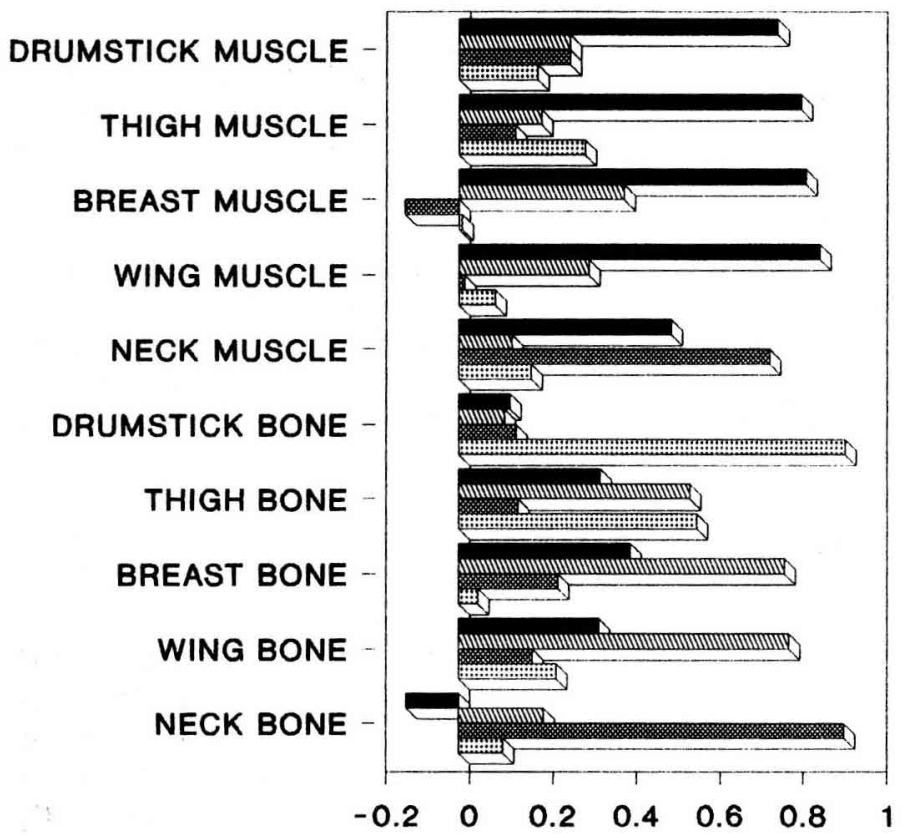

Fig 1. Correlations between factor score coefficients and original variables. lations between factors were zero. The second factor gave relatively little weight to the drumstick bone and accounted for an additional $14.8 \%$ of the total variation. Variables associated with the wing bone had the highest loadings on it, followed by those associated with the breast bone and thigh bone. This factor could be called bone factor.

The third factor accounted for $8.8 \%$ of the total variation and had high loadings on the neck muscle and bone and could be called neck factor. The neck in ducks is thick, long and very flexible and its skeleton is composed of 15 cervical vertebrea. The neck structures and functions enable the bird to maintain its balance and to shift its center of gravity for running and flying. Ducks are known for their capacity to fly long distances.
The fourth factor accounted for $6.7 \%$ of the total variation, with the drumstick bone having the highest loadings. It could be called the drumstick bone factor or tibia factor or weight support factor. The tibia in ducks is about twice as long as the femur, while in the chicken and turkey it is about one and one-half as long as the femur. Generally, the drumstick region (distal hind leg) is essential for locomotion (walking and perching), and is responsible, in part, for supporting the weight of the bird. Wright $(1932,1954)$ used factor analysis to identify factors that control the bone dimensions in White Leghorn fowls and found that the proportions of the variability determined by the three common factors are $73.8,6.3$ and $1.8 \%$, respectively, leaving $18.1 \%$ to the six unique factors. He 
found that leg and wing measurements depend on a common factor, which is not operative on the head.

In summary, most of the common variabilities in meatiness and bone traits could be accounted for by factors representing muscles, bone, neck and drumstick bone.

\section{INDEPENDENT FACTOR SCORES AND THEIR RELATIONSHIP WITH TOTAL SIDE MUSCLE AND TOTAL SIDE BONE WEIGHTS}

Correlations between varimax rotated factor scores and total muscle weight ranged from 0.08 to 0.899 and between factor scores and total side bone ranged from 0.311 to 0.682 . The correlation between FC1 and total side muscle weight was 0.899 and that between FC2 and total side bone weight was 0.682. Ricard and Rouvier (1966), working with chickens, found that the genetic correlations of the first (size) and second (compactness) factors with muscle/bone deviation were 0.223 and 0.336 , respectively. Ricard (1980) suggested that the cor- relation between general size and meatiness in Muscovy ducks seems to be high and positive.

Meatiness factor score alone accounted for $81 \%$ of the variation in the total side muscle weight. Results of a stepwise multiple regression of total size muscle weight on the four varimax factor scores (table VII) showed that $R^{2}$ increased from 0.94 to 0.96 and the RSD of the estimate decreased from 17.6 to $7.7 \mathrm{~g}$ as FC2, FC4 and FC3 orthogonal factor scores were added stepwise. The final multiple regression equation for estimating total side muscle weight from independent factor scores was:

Total side muscle $(\mathrm{kg})=235.52+36.02$ $\mathrm{FC} 1+14.72 \mathrm{FC}_{2}+4.68 \mathrm{FC} 4+3.22 \mathrm{FC} 3$

Bone factor score (FC2) alone accounted for $47 \%$ of the variation in total side bone weight. The results of a stepwise multiple regression of total side bone weight on the four varimax factor scores (table VIII) showed that $R^{2}$ increased from 0.65 to 0.91 and the RSD of the estimate decreased from

Table VII. Stepwise multiple regression of total side muscle weight $(\mathrm{g})$ on orthogonal factor scores.

\begin{tabular}{|c|c|c|c|c|c|c|}
\hline Step & $\begin{array}{l}\text { Independent variables } \\
\text { (predictors) }\end{array}$ & Intercept & $\begin{array}{l}\text { Regression } \\
\text { coefficient } b\end{array}$ & $S E$ & $\mathrm{R}^{2}$ & $\begin{array}{c}\text { Residual } \\
\text { standard deviation }\end{array}$ \\
\hline - & $. \quad-$ & - & - & - & - & - \\
\hline 1 & FC1 & 235.52 & 36.02 & 1.47 & 0.809 & 17.58 \\
\hline 2 & $\begin{array}{l}\text { FC1 } \\
\text { FC2 }\end{array}$ & 235.52 & $\begin{array}{l}36.02 \\
14.72\end{array}$ & $\begin{array}{l}0.79 \\
0.79\end{array}$ & 0.944 & 9.55 \\
\hline 3 & $\begin{array}{l}\text { FC1 } \\
\text { FC2 } \\
\text { FC4 }\end{array}$ & 235.52 & $\begin{array}{r}36.02 \\
14.72 \\
4.68\end{array}$ & $\begin{array}{l}0.70 \\
0.70 \\
0.70\end{array}$ & 0.958 & 8.34 \\
\hline 4 & $\begin{array}{l}\text { FC1 } \\
\text { FC2 } \\
\text { FC4 } \\
\text { FC3 }\end{array}$ & 235.52 & $\begin{array}{r}36.02 \\
14.72 \\
4.68 \\
3.22\end{array}$ & $\begin{array}{l}0.64 \\
0.64 \\
0.64 \\
0.64\end{array}$ & 0.964 & 7.71 \\
\hline
\end{tabular}


Table VIII. Stepwise multiple regression of total side bone weight $(\mathrm{g})$ on orthogonal factor scores.

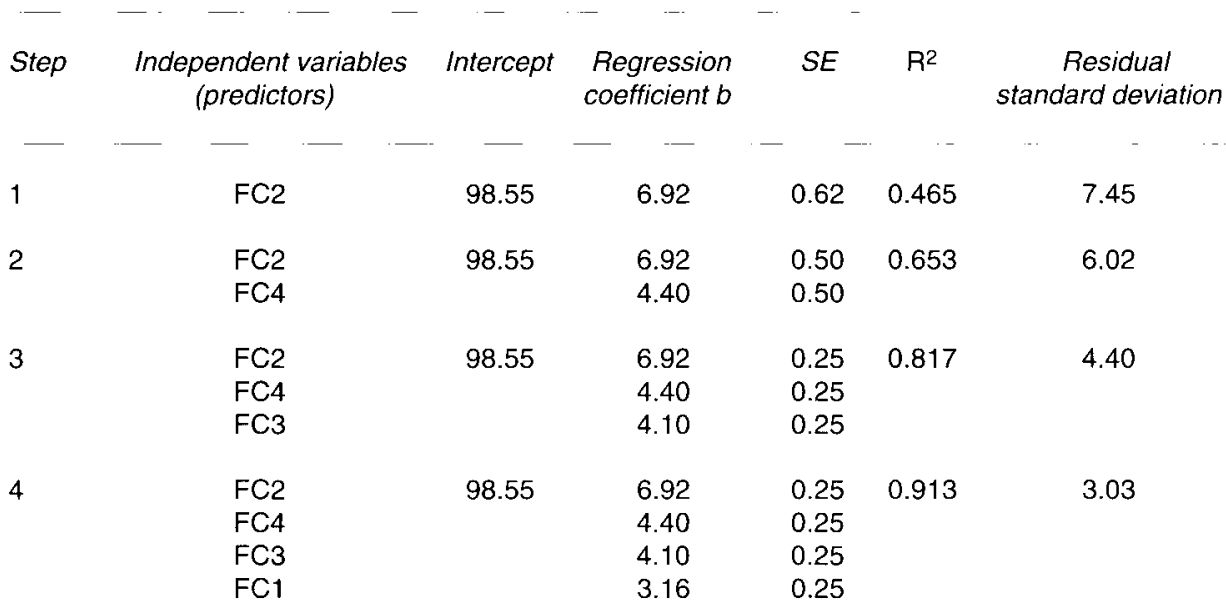

6.02 to $3.03 \mathrm{~g}$ as FC4, FC3 and FC1 orthogonal factor scores were added in stepwise. The final multiple regression equation for estimating total side bone weight from independent factor scores was:

Total side bone $(\mathrm{kg})=98.55+6.92 \mathrm{FC} 2+$ $4.40 \mathrm{FC} 4+4.10 \mathrm{FC} 3+3.16 \mathrm{FC} 1$

Tables VII and VIII show that the regression coefficients in a stepwise multiple regression of total side muscle and total side bone against the four orthogonal varimax factors were stable and did not change with the addition of variables in the equation (order of entry did not affect the results). Corresponding regression coefficients obtained from regressing total side muscle and total side bone on original intercorrelated variables (nonorthogonal) (tables IV and $V$ ) were unstable and sensitive to the addition of variables in the equations. This instability rendered it impossible to estimate the unique effects of individual variables in the regression equation and thus, could lead to false inferences.

\section{VARIABILITY OF NONINDEPENDENT MUSCLE AND BONE TRAITS}

The overall variability of bone traits was lower than that of flesh traits (table I).

Table IX lists the commonalities $h^{2}$ and uniqueness $u^{2}$ ( 1 minus commonality) for

Table IX. Common and unique factors for each variable.

\section{Common factor Unique factor $h^{2} \quad u^{2}$}

$\begin{array}{lll}\text { Drumstick muscle } & 0.763 & 0.237 \\ \text { Thigh muscle } & 0.824 & 0.176 \\ \text { Breast muscle } & 0.864 & 0.136 \\ \text { Wing muscle } & 0.852 & 0.148 \\ \text { Neck muscle } & 0.861 & 0.139 \\ \text { Drumstick bone } & 0.905 & 0.095 \\ \text { Thigh bone } & 0.768 & 0.232 \\ \text { Breast bone } & 0.845 & 0.155 \\ \text { Wing bone } & 0.826 & 0.174 \\ \text { Neck bone } & 0.920 & 0.080\end{array}$


Fig 2. Commonality for each variable.

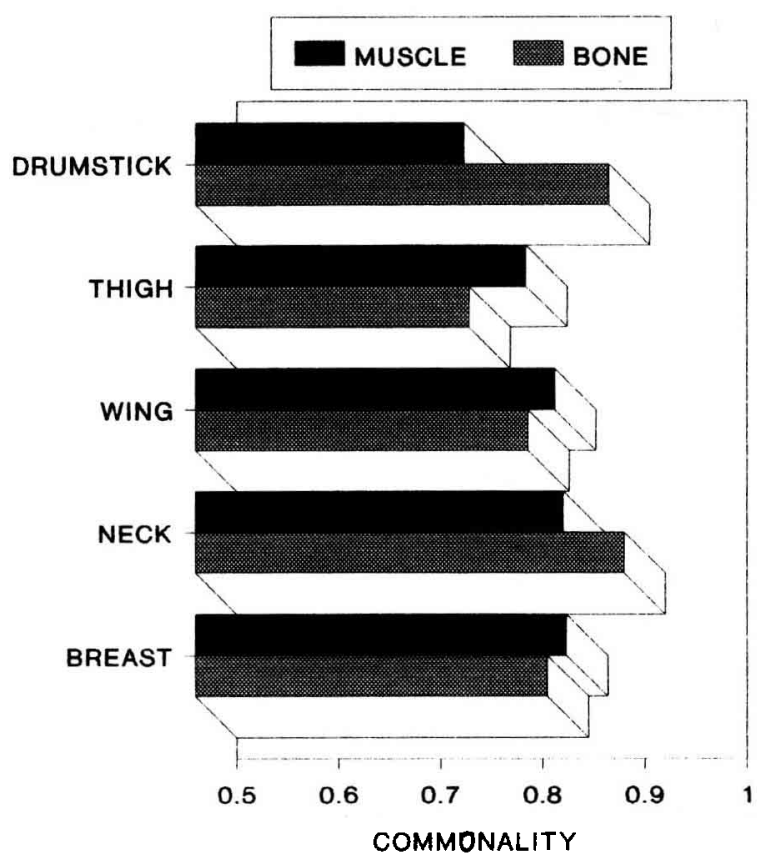

several variables. The variance of a variable was partitioned into a common portion, shared with some or all the other variable 'commonalities', and a portion unique to that particular variable, which was not shared with any other variable 'uniqueness'. The results indicated that about 76 to $92 \%$ of the variation in meatiness and bone traits were brought about by the common factors, whereas 8 to $24 \%$ of their variations were contributed by unique factors, specific for each trait.

The commonalities for muscle traits ranged from 0.763 for the drumstick muscle to 0.864 for the breast muscle and those for bone traits ranged from 0.768 for the thigh bone to 0.920 for the neck bone (fig 2). The drumstick muscle and the thigh bone had the lowest commonality with the greatest uniqueness of their own. Approximately $76-77 \%$ of the variation in the drumstick muscle and thigh bone was brought about by common factors, whereas $23-24 \%$ of their variations were contributed by the unique factor specific for each of the drumstick muscles or thigh bones.

\section{CONCLUSION}

With the ever-growing demand for lean meat, there is an urgent need for rapid, accurate and efficient methods for assessing the total amount of carcass muscle. Studies have shown that total dissection is one of the best methods for estimating the total composition of a bird. However, as this technique is either time-consuming, expensive or both, simplified methods for assessing total muscle and bone in the carcass would be of value to workers in the meat industry and in meat research.

Clear-cut advantages of the factor analysis technique appeared when the information in the ten meatiness and bone traits was consolidated into four advantageously inter- 
pretable factors which then clarified the relationship between the weights of muscle and bone in various cuts with the corresponding weight of that tissue in the carcass.

\section{REFERENCES}

Blackith RE, Reyment RA (1971) Multivariate morphometrics. Academic Press, London, New York

Chatterjee S, Price B (1977) Analysis of collinear data. In: Regression analysis by examples. John Wiley \& Sons, New York, chapter 7, 143-174

Clayton GA, Draper MH (1971) Table ducks: meat content and skeletal development. Br Poult Sci 12, 225-229

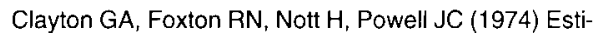
mating carcass composition in the duck (Anas Platyrhynchos). Br Poult Sci 15, 153-158

Cole JW, Orme LE, Kincaid CM (1960) Relationship of loin eye area, separable lean of various beef cuts and carcass measurements to total carcass lean in beef. J Anim Sci 19, 89-100

Cox AC, Balloun SL (1971) Prediction of total skeleton mineralization from individual bone data. Poult Sci50, 186-194

Draper NR, Smith $H$ (1981) Applied regression analysis, 2nd edn. John Wiley \& Sons, New York, NY, USA

Herstad O, Frisch J (1972) Methods for estimating meatiness and bone content in broiler carcasses. Acta Agric Scand 22, 17-21

Janiszewska M, Lewezuk A, Bochno R (1983) The use of multiple regression equation for the evaluation of carcass composition of ducks from different lines. Anim Breed Abstr 52, 6154

Kaiser HF (1958) The varimax criterion for analytic rotation in factor analysis. Psychometrika 23, 187-200

Klijn HB (1976) An analysis of muscle weight variations in the wing and leg of Sturnus vulgaris. Anat Embryol $149,259-287$

Martin WG, Patrick H (1962) Radionuclide mineral studies. 4. Studies on the metabolism of $\mathrm{Ca}^{45}$ by the chick. Poult Sci 41, 213-219

Mather PM (1976) Computational methods of multivariate analysis in physical geography. John Wiley \& Sons, London

Morris TR, Brookhouse JK, Taylor TG (1966) The prediction of skeletal weight from the weights of sample bones. Br Poult Sci 153-157 (research note)

Morrison DF (1967) Multivariate statistical methods. McGraw-Hill Book Co, New York, NY, USA

Pimentel RA (1979) Morphometrics. The multivariate analysis of biological data. Kendall/Hunt Publishing Company, IA, USA
Ricard FH (1972) Study of the anatomical composition of the chicken. IV. Possibilities of estimating carcass meat, bone and skin yields by means of simplified limb dissection. Ann Zootech 21, 49-57

Ricard FH (1980) Carcass conformation of poultry and game birds. In: Meat quality in poultry and game birds (GC Mead, F Freeman, eds), Br Poult Sci (Edinburgh) 31-50

Ricard FH (1987) Anatomical characteristics of female Muscovy duckling carcasses. Ann Zootech 36, 109 120

Ricard FH, Rouvier R (1966) A study of conformation measurements in the fowl. IV. Genetic variability of carcass measurements and meat/bone deviation in Bresse-Pile cockerels. Ann Zootech 15, 197-269

Rouvier R, Ricard FH (1967) Study of the anatomical composition of chicken. It. Variability of the distribution of meat and bone in Bresse-Pile cockerels. Ann Zootech 16, 357-374

SAS (1988) SAS user's guide. Statistical Analysis System Institute, Inc, Cary, NC, USA

Shahin KA (1990) Phenotypic and genetic parameters for muscle weight distribution in Pekin ducklings. Arch Geflugelk 54, 199-203

Shahin KA, Soliman AM, Moukhtar AE (1993) Sources of shared variability for the Egyptian buffalo body shape (conformation). Livest Prod Sci 36, 323-334

Stasko J (1965) The heritability of the size of the femoral and breast muscle and other characters in a 56-dayold duckling. Zivocina Vyroba 70, 837-842

Stopher PR, Meyburg AH (1979) Rudiments of factor analysis. In: Survey sampling and multivariate analysis for social scientists and engineers. Lexington Books, DC Health and Company, Lexington, MA, Toronto, chapter 11, 237-261

Williams DR, Pomeroy RW, Harries JM, Ryan PO (1974) Composition of beef carcasses. II. The use of regression equations to estimate total tissue components from observations on intact and quartered sides and partial dissection data. J Agric Sci (Camb) 83, 79-85

Wright $S$ (1932) General, group and special size factors. Genetics 17, 603-619

Wright $S$ (1954) The interpretation of multivariate systems. In: Statistics and mathematics in biology $(O$ Kempthorn, TA Bancroft, JW Gowen, JL Lush, eds), The lowa State College Press, Ames, IA, USA, Chapter 2, 11-33

Wawro K, Bochno R, Wawro E (1984) The suitability of weight of some muscles for predicting tissue composition of carcasses of ducks slaughtered at different ages. Zeszyty Naukowe Akademii RolniczoTechniczejw Olsztynie no 257. Zootechnika 27, 173-181

Wawro K, Bochno R, Wawro E, Janiszewska M (1985) The use of multiple regression coefficients for evaluation of Italian, Kuban and crossbred geese. Prace Materialy Zootechniczne 34, 77-88 